\title{
Erratum to: A glucosinolate-rich extract of Japanese Daikon perturbs carcinogen-metabolizing enzyme systems in rat, being a potent inducer of hepatic glutathione $S$-transferase
}

\author{
Ahmad Faizal Abdull Razis - Gina Rosalinda De Nicola • \\ Eleonora Pagnotta - Renato Iori - Costas Ioannides
}

Published online: 29 July 2012

(C) Springer-Verlag 2012

\section{Erratum to: Eur J Nutr}

DOI 10.1007/s00394-012-0397-2

The original version of this article unfortunately contained incorrect author affiliations. The correct information is given here.

The online version of the original article can be found under doi:10.1007/s00394-012-0397-2.

\footnotetext{
A. F. Abdull Razis · C. Ioannides ( $\square)$

Molecular Toxicology Group, Faculty of Health and Medical Sciences, University of Surrey, Guildford, Surrey GU2 7XH, UK

e-mail: c.ioannides@surrey.ac.uk
}

Present Address:

A. F. Abdull Razis

Department Food Science, Faculty of Food Science

and Technology, Universiti Putra Malaysia (UPM),

43400 Serdang, Selangor, Malaysia

G. R. De Nicola $\cdot$ E. Pagnotta $\cdot$ R. Iori

Agricultural Research Council, Industrial Crop Research Centre

(CRA-CIN), Via di Corticella, 133, 40128 Bologna, Italy 